\title{
\$sciendo
}

Ethics \& Bioethics (in Central Europe), 2018, 8 (1-2), 41-50

DOI:10.2478/ebce-2018-0008

\section{Spinozian consequentialism of ethics of social consequences}

\author{
Michaela Petrufová Joppová ${ }^{1}$
}

\begin{abstract}
The present article deals with specific normative concepts of Spinoza's ethical system and compares them to certain aspects of the theory of ethics of social consequences. At first, a way to approach the problem of normativity in Spinoza is presented, concentrating on the obligatory character of rational - or intellectual motives. Then, theoretical evidence is presented which links Spinoza to normative-ethical consequentialism. The basis for a consequentialist model of Spinoza's ethics is the concept of perfection, and on this basis it seems possible to consider its compatibility with non-utilitarian forms of consequentialism, such as ethics of social consequences. Conclusively, the paper's aim is to present the possibility of considering Spinozian consequentialism as a non-utilitarian consequentialism, while considering ethics of social consequences as a contemporary form of Spinozian consequentialism.
\end{abstract}

Keywords: Spinoza, rationality, morality, consequentialism, ethics of social consequences

\section{Introduction}

The philosophical ethics of Baruch Spinoza is mostly regarded as a descriptive, rather than prescriptive ethical theory, not holding onto strict specific positions about right or wrong, recommended or not recommended moral actions, etc. His thinking could be characterized as more meta-ethical than ethical, as it was focused on revealing the origin and nature of our moral reality, rather than simply "play by its rules". That also means that for Spinoza, there is no actual moral reality; there is nothing morally, or in any other way valuable, and the meaning of human action is mostly the same as the meaning of a bird singing or chirping to its mates. It is all part of one ultimate reality, the substance, which cannot be termed moral at all. And since reality, or substance, provides no basis for definitive moral judgments, assertions, prescriptions, or statements, it should be on one's mind to avoid holding any specific normative-ethical position except for intellectual adoration of the substance and its nature.

It is true, then, that Spinoza holds no specific normative-ethical position that would not regard the substance, except maybe for the conatus doctrine, which was prevalent in the philosophy of the early modern period (Carriero, 2011, p. 69). However, from his conatusbased meta-ethically conceived concepts of good and evil, one can abstract ethically functional - and prescriptive - constituents for an ethical theory. The aim of the paper is to define these prescriptive constituents in an attempt to formulate a normative account of Spinozian ethics, which I believe could be articulated and understood as a type of consequentialist ethics. I will then try to compare this "Spinozian consequentialism" with a contemporary non-utilitarian form of consequentialist ethical theory, ethics of social consequences.

\section{Normative moments in Spinoza's ethics}

Though rationalist, the result of Spinoza's ethics is not some transcendental ideal or criterion of morality, as found in Kant; nor is such an ideal the basis for his ethics. Spinoza builds his conception of moral agency through naturalistic anthropology, identifying moral ideas and moral acts as ideas and acts in the first place, thus not granting morality any special transcendental place, but identifying it with human nature as part of nature. Humans act

\footnotetext{
${ }^{1}$ University of Prešov (Slovakia); email: michaela.joppova@ smail.unipo.sk
} 
mostly in accordance with their deeply-rooted desire for self-preservation, such as every other thing in nature: "For it is manifest that no thing could, through its own nature, seek its own annihilation, but, on the contrary, that every thing has in itself a striving to preserve its condition and to improve itself" (Spinoza, 2002c, p. 53). This striving, or conatus, is not conceived merely as some attribute of a thing, but rather as the thing itself, i.e., it is identified with a thing's own existence and nature: "For although the thing and its conatus are distinguished by reason, or rather, by words (and this is the main cause of their error), the two are in no way distinct from one another in reality" (Spinoza, 2002b, p. 188). It is this conatus, that is the source of every conceivable human faculty and ability, including emotions, reason, will, and morality. The starting point of morality can thus be found in the thing's existence itself, contrary to Kant putting it at the boundaries of reason.

Spinoza does not specifically define morality in any of his works. In the few places which morality is mentioned, it is closely associated with knowledge, as in "true knowledge and true morality" (Spinoza, 2002d, p. 405). His view of morality is cognitivist in the sense of believing that the state and progress of one's cognitive abilities directly affect one's morality. At times it even seems that for Spinoza, cognition and morality are regarded as one and the same thing; the more rational a person is, the more active s/he is in the context of moral agency, which implies that rationality and moral agency are fundamentally identical. However, Spinoza's concept of moral agency is not based on autonomy of reason, as in Kant's ethics. Since the only thing that can be ever termed autonomous in the strictly metaphysical sense is the substance, it would be absurd to state autonomy as specific of human reason. Rationality, moral agency, and the activity of the mind as a whole emanate from the faculty of conceiving adequate ideas, or, the faculty of understanding. And while the faculty of understanding is a necessary precondition of morality, it is also considered as morality's end - the highest virtue that a human being is capable of.

It could be stated that for Spinoza, the ultimate ethical end is the possession of knowledge (De Dijn, 2004, p. 37). What is the role of reason in advancing on this end? Since reason is simply one of many finite modes of thinking, it would be reductive to concentrate on perfecting reason alone; rational knowledge is neither complex nor concrete enough to lead to the highest form of human perfection. True, adequate knowledge consists of having adequate ideas - or simply ideas, as Spinoza considers an idea as "the very act of understanding" (Spinoza, 2002a, p. 269) - and the activity of the mind, which is fundamentally one and the same thing. True understanding is the highest form of activity of the mind, and since the activity of the mind can be nothing else than thinking, understanding represents thinking in its truest, most complex form. The performance of rationality is based on "common notions and adequate ideas of properties of things" (Spinoza, 2002a, p. 267), but it does not necessarily lead to understanding things' essences, i.e., their adequate ideas. Reason functions more like an instrument for staying on the level of adequacy of thinking (through conceiving adequate properties of things), but it is not the ethical end-in-itself.

Since a rational being understands the role of reason in moral decisions and actions, it follows from Spinoza's thinking that the more rational a person is, the more obliged s/he is to further develop and improve his/her rationality. Only through this rational effort humans are able to develop into a state of blessedness, which consists of understanding knowledge (or love) of the substance (or God); adequate knowledge of God being the final goal of human existence. Reason alone may incline towards the adequate, but, as Spinoza puts it, "there is no rational life without understanding" (Spinoza, 2002a, p. 358), and to understand God, humans must first perfect their understanding (or intellect) as such. Spinoza also claims that the intellect is the only part of the mind through which we are said to be active, and the only part of the mind that is eternal (Spinoza, 2002a, p. 381). The ethical ideal of the Ethics is the ideal of human agency, which consists of being completely active in thinking and in bodily action. 
It follows, then, that constant improvement of one's understanding is the supreme ethical goal, and supreme obligation for any rational (and thus understanding) being.

Normative moments of obligation in Spinoza may also be found in the concept, or ideal, of human nature. Spinoza's philosophy features the concept of human nature as a rational project or construct (ens rationis) that each rational human constructs by himself and for himself, and which serves as a model of humanity that this particular human being lives according to. That means that through reason, rational agents are able to construct the scope of their own moral rationality, demonstrated in their idea of humanity which they apply to themselves. In the context of this normative character of human nature, it is necessary to differentiate between two possible levels of prescriptive ethics: obligations for rational persons, and obligations for irrational - or significantly less rational - persons. Michael LeBuffe defends this interpretation of normativity in Spinoza on the grounds that there are many things which may benefit a person who desires them in the right way, but that will not benefit a person who does not; for example, food and drink are good things for someone who desires them through reason, but might be bad for someone who desires them from passion (LeBuffe, 2007, p. 383). We could say that for irrational persons, the supreme moral obligation is to try to overcome their passions by rational activity and self-reflectivity. For greatly rational persons, the supreme moral obligation is to try to become eternal to a great extent, i.e., perfecting the intellect towards the conscious love of God. And for moderately rational persons - probably the majority of people - the supreme obligation is constant improvement of reason and intellect so that they help them advance towards their own ideals of themselves.

What may still seem unclear is the background of these obligations; in other words, where do obligations come from? Since there is no transcendental eternal reason guaranteeing the adequacy of judgments of practical rationality, and also within human beings there is no inherent "pure" reason which could faultlessly guide their minds, who or what exactly obliges us to do something? As I believe is already evident, Spinoza conceives obligations on rational grounds; in fact, they could be conceived as necessary expressions of rationality's selfaffirming character. All of Spinozian ethics is based on this self-affirming character of rationality: morality does not exist before rationality and intellectuality. A person that is rational is, in Spinoza's view, also moral, in the sense that as long as s/he uses her/his rationality, it morally obliges him/her to use it even more and in a more perfect way. Supreme ethical obligations are then either pursuit, or improvement, or perfection of one's rationality, which apply to irrational, moderately rational, or greatly rational minds. Since all obligations must endorse rationality and not invalidate its self-affirming essence, they must comply with the basic principle of rationality - the principle of non-contradictionality. In this context, Spinoza remarks: "If a free man, insofar as he is free, were to act deceitfully, he would be doing so in accordance with the dictates of reason (for it is in this respect only that we term him free), and thus to act deceitfully would be a virtue, and consequently, [...] it would be better for every man to act deceitfully, that is (as is self-evident), it would be better for men to agree in the words only, but to be contrary to one another in reality, which is absurd" (Spinoza, 2002a, p. 357).

We can see that for Spinoza, when a greatly rational mind - or a free $\operatorname{man}^{2}$ - is guided by reason, it should prohibit him from unreasonable, even nonsensical action, i.e., an action that

\footnotetext{
${ }^{2}$ I understand Spinoza's concept of a free man as the concept of a human being with a moderately to greatly rational mind, that is, a man who understands himself as a rational being, tries to overcome his weaknesses by rational effort and tries to perfect and realize his adoration for reality, or God. Karolina Hübner, for example, interprets the concept of a free man in Spinoza in a very idealistic and internalist-oriented manner, as she finds Spinoza's model of human nature to represent what she calls a "pure reasoner", i.e., an ideal being that exists only qua reasoning. For such a being, external causes are neither needed, nor do they obstruct his actions (Hübner, 2014, p. 138). While I think that such a concept of a free man might be adequate for hypothetical reasoning, I find the most viable concept of a free man to be the one that acknowledges the external "dangers"
} 
consists of contradiction. So in practice, the principle of non-contradictionality, funded by reason alone, might serve as a quick tool to check one's motive, goal, or the content of an action in relation to its rationality. ${ }^{3}$ The cognitivist and rationalist orientation of Spinoza's ethics implies that whenever an action is rational, it is also moral, or good, but one must adequately understand the true nature of rationality to use it the right way. And how do we use our rationality in the right way? When we do not separate it from understanding, and do not forget that true understanding is the ultimate ethical goal, while rationality is just a tool we use in the process of its attainment.

\section{Spinozian consequentialism...}

The normativity of Spinoza's ethics lies primarily in the "dictates of reason": rational human beings ought to act according to their rationality, which proves to be, when considered in relation to ethics, the "safest" mode of thinking since it gravitates towards common notions and properties. That means that through rationality, human beings are more prone to come to an agreement when it comes to establishing moral rules and norms, and choosing the principles that would guide them. Rational thinking also tends to be consistent, and so it enables the moral agent to build his own structure of values that he consistently finds appealing, respectable, or motivating. It needs to be stressed that according to Spinoza's gnoseology, the purpose of rationality is abstraction, construction, and regulation, so its "ethical" usefulness lies primarily in constructing ideals and abstractions that guide our action. The fundamental categories governing our thinking and action in the moral sense are good and evil.

Spinoza's naturalism identifies good and evil with their subjective source, i.e., subjective judgment based on what a person likes or doesn't like. And since good and evil are subjective categories, it is better to construct the model of good and evil based on the chosen model of human nature, rather than on our desires, appeals, and the like. Spinoza advances this way and constructs a model of good and evil based on his model of a free man, or a greatly rational mind: "So in what follows I shall mean by 'good' that which we certainly know to be the means for our approaching nearer to the model of human nature that we set before ourselves, and by 'bad' that which we certainly know prevents us from reproducing the said model" (Spinoza, 2002a, p. 322).

Good and evil are thus ethical constructs with normative power similar to the concept of human nature. But this is not a common ethical meaning which people normally ascribe to these terms. Surely when a person terms something good, s/he needs not have a concept of human nature guiding his/her action. Yitzhak Y. Melamed explains that according to Spinoza, when people say that a certain act or certain event is evil, what they actually do is compare it with a certain kind of perfection it could have had, while also admittedly judging that it could have been better. Evil, then, is merely a privation of a more perfect state (Melamed, 2011, p. 157).

Spinoza illustrates this using the Garden of Eden, specifically concerning Adam's fall. In one of his letters, he replies to Willem van Blyenbergh's question whether Adam's decision (to eat the forbidden fruit and deceive God) was good or bad, and whether or not he was simply executing God's will. Spinoza responds that Adam's decision was neither evil nor -

\footnotetext{
placed upon him and where he tries to overcome his passions by recognizing them as part of himself. Such a concept is presented, for example, by Matthew Homan (2015).

${ }^{3}$ This strongly resembles the practical purpose of Kant's categorical imperative, one of possible final statements of dogmatic rationalist ethics. However, since Kant's relation to Spinoza has been spectacularly overlooked over the years, I do not engage in comparing Spinozian and Kantian ethical systems, though some interesting parallels definitely seem to come forward. In recent years, some progress regarding the relationship between these two great rationalists has been made by Omri Boehm (2014), who argues that at the very least, the pre-critical Kant was likely a Spinozist.
} 
improperly speaking - against God's will, because in the end God must have been the cause of it, as he is the cause of everything. But distinguished evil lies in the privation of a more perfect state, which Adam was bound to lose because of his actions (Spinoza, 2002e, p. 809). How are we supposed to judge Adam's action, then? We cannot adequately judge his action of deceiving God according to his motive, because he was the one who was deceived in the first place, and thus in the moment of the said action he was deprived of a large part of his rationality (knowing the truth). If he was not rational enough, the influence of obligations which would normally apply to him - namely improving his rationality by committing rational acts - declines. So, strictly speaking, his action may have been contradicting in itself, because it was based on deceit, but we shall not perceive it as contra-obligatory, because it was not based on evil motives.

We might say that good motives are based on adequate understanding; but what makes an act good? When we cannot adequately judge an act according to its motive, we can still surely judge it by means of something else. In the case of Adam, we can definitely judge his actions by the consequences it produced, i.e., the privation of a more perfect state. In Spinoza's ethics, actions seem to be measured according to one fundamental criterion: whether they consequentially increase or decrease perfection. If we define human perfection as the complete activity of the mind and body funded by the intellect, then actions are morally good when they produce consequences that increase such intellectual activity of a moral agent, and morally bad when they decrease such activity. Only actions of a moral agent that not only motivationally, but also consequentially affirm his rational and intellectual nature are thus termed to be good. A particular act is then perfectly morally good when it is based on good motives (i.e., adequate understanding), and when it simultaneously produces consequences that increase perfection and evade privation. Formulated as an obligation, this Spinozian concept bears striking resemblance to the utilitarian principle of maximizing utility, which Jan Narveson states as: "We ought always to [sic] maximize the good, as each person sees it, so far as possible" (Narveson, 1970, p. 276). However, it is necessary to change the part of "as each person sees it" to "according to each one's essence".

We can see that there is a distinctively pronounced component part of Spinoza's moral philosophy that could be likened to consequentialist normative-ethical thinking. According to Ján Kalajtzidis, consequentialist ethical theories are those that evaluate and judge the actions of a moral agent according to their consequences; nevertheless, he stresses that consequences are just one of many ways of evaluating acts, though in consequentialism it is the most important one (Kalajtzidis, 2013, p. 163). Vasil Gluchman differentiates between utilitarian and non-utilitarian consequentialism, that diverge at the following moments: a) non-utilitarian consequentialism (NC) avoids the reduction of consequences to an action, as in utilitarian consequentialism (UC), and also considers the consequences of a motive, an attitude, or an intent; b) the structure of values in NC is more broadly conceived than in UC, not reduced to utilitarian values; c) UC considers as right only such an action that produces the best possible consequences (maximizing principle), while in $\mathrm{NC}$ an action can be termed right even when it produces "only" a prevalence of good consequences. Another dividing moment may be the refusal of the impartiality principle of UC by NC (Gluchman, 1995, p. 53).

Which consequentialism would Spinoza prefer - UC or NC? There are many moments linking him to utilitarianism, for example his methodical use of eudaimonistic, hedonistic or utilitarian approaches in solving ethical questions, as Gluchman observes (Gluchman, 1996, p. 72). However, I fully agree with Federico Zuolo and arguments regarding utility in Spinoza presented in his recent work Nature and morals (2016), in which he argues that for Spinoza, the utility of an action is always associated with one's power of preserving his existence, i.e., with his conatus, and that ethical life should be understood only in terms of relative increasing and decreasing of this power. Since the perfection of conatus is identical with perfection of 
mental and physical activity, and humans are most active - and eternal - when they adequately understand, the distinguished utility of an action is always linked to the intellect, which is the source for the mind's power to exist in eternity. Spinoza's conception of utility was more metaphysical or epistemological utilitarianism, than the ethical form of it. ${ }^{4}$ There are many situations in which we have the opportunity to increase the utility of our actions by using methods that are contrary to our rational essence, and I believe I have sufficiently demonstrated that Spinoza would definitely not encourage them. Spinoza's ethical theory is perfection-oriented, but does not ethically place one's own perfection prior to the perfection of the world. One's action does not only increase or decrease one's own perfection, but also social or natural perfection, and these perfections, when we specify them as values, do not depend upon the perfection of our intellect. I believe, then, that it is adequate to consider Spinozian consequentialism as a form of NC.

\section{... and ethics of social consequences}

Let us take a closer look at what a specific type of non-utilitarian consequentialist ethical theory might look like. I have chosen ethics of social consequences, which is probably the most potent consequentialist ethical theory in our region. Originally conceived by the Slovak philosopher Vasil Gluchman, ethics of social consequences refuses the maximizing principle of UC and works within broader ethical contexts. The determining criterion of morality in this theory is positive social consequences, i.e., the totality of consequences with positive character or influence resulting from the actions of moral agents. Secondary criteria used as a means for measuring the consequences are also present - the motives and intentions of actions - however, they are inseparably bound to the consequences they lead to through actions (Gluchman, 1995, p. 85). Gluchman defines positive social consequences as a relative concept that can have different, even almost seemingly ambivalent content under different circumstances. One cannot say, for example, that unemployment is always a negative phenomenon with regard to society, because he has to recognize its effects in respect to concrete people and their lives, fates, plans, interests etc. (Gluchman, 2003, p. 17). Such a relative concept of positivity or negativity of consequences echoes with Spinoza's understanding of the relative nature of good and evil and their subjective origins.

Ethics of social consequences presents a dualistic account of moral evaluation of actions: one is based on the theory of moral (or the theory of value), the other on the theory of right. According to Kalajtzidis, the theory of good conceptualizes what is valuable and what we should aspire to, while the theory of right tries to stabilize what one should choose, or which option (out of at least two of them) is the right one (Kalajtzidis, 2013, p. 160). So from the viewpoint of these evaluating standpoints, an action is considered moral if there is a maximum or a greatly significant prevalence of positive over negative consequences, and is considered right if the prevalence of positive over negative consequences is less significant. If there is a maximum or greatly significant prevalence of negative over positive consequences, and action is considered immoral, and is considered wrong if there is a more minor prevalence of negative consequences over the positive ones (Gluchman, 2017, p. 58). It seems that these evaluating standpoints make no place for considering motives as a criterion of morality or moral content of an action, which would drastically differ from Spinoza's view of our

\footnotetext{
${ }^{4}$ Most utilitarian aspects of Spinoza's ethics derive from his epistemological or intellectual egoism based on one's conatus and the power of knowledge in preserving one's being. However, I fully agree with Herman De Dijn (1996) that within Spinoza's account of morality, this metaphysical egoism is not compatible with ethical, utilitarian egoism. The basic principle of egoism, preserving one's being at any cost, is not ethically advised by Spinoza. In Ethics, for example, he argues that reason forbids us from deceiving other people even though it would free us from the danger of imminent death (Spinoza, 2002a, p. 357). So preserving one's being does not seem to be the supreme utilitarian goal, nor does one's death seem to be the worst possible moral consequence.
} 
obligations towards the intellect. Gluchman, however, reacts to this possible objection by considering actions as moral or immoral, praiseworthy or blameworthy based on the intentions of moral agents (Gluchman, 2001).

To put it most simply, when taking motives into account, ethics of social consequences distinguishes between: 1. moral, right, and wrong action, in case of an action being based on good motives, and 2. immoral, wrong, and right action, in case of an action being based on bad motives (Gluchman, 2008, p. 15). We can thus see that even though this is theory proposed as consequentialist, its concept of moral good (or the idea of good, to put it in Spinozian terms) somehow depends on what the moral agent wills to do - and why. The "why" of the action makes up its morality; the "what" of the action determines its rightness or wrongness. If we apply Spinoza's demand for an increase in perfection to the claim that the rightness or wrongness of an action depends on the measure of positive or negative consequences it produces, we can specify the criteria for evaluating an action as following:

1a) an action is moral if it's based on good motives, that is, on adequate understanding (ideas), such as intuition, reason, or good passions;

1b) an action is immoral if it's based on bad motives, that is, on inadequate understanding (ideas), such as bad passions;

2a) an action is right if it causes the prevalence of effects (consequences) that increase perfection over effects that decrease it;

$2 b)$ an action is wrong if it causes the prevalence of effects (consequences) that decrease perfection over effects than increase it.

I believe that this summarizing account of two different evaluating standpoints respects and does justice to both Spinoza's ethics and ethics of social consequences. In a Spinozian view, it is as much good and desirable to be the adequate cause of one's activity, and thus perfect the intellect and act according to adequate motives, as it is good and desirable to be the cause of an action that causes effects of increasing perfection, i.e., positive consequences. This is the essence of the ethical indissolubleness of theoretical and practical, or, adequate understanding and its active realization. Ethics of social consequences also hints at this by conceptually dividing the motivational and consequential aspects of moral evaluation, and I believe that such a coherent ethical vision is a necessary precondition for establishing adequate ethical theory which would support adequate moral practice.

As Gluchman correctly points out, there are two stages of understanding of the good in Spinoza's ethics: at the first stage there is a relativistic concept of good, touching mainly practice, with utility regarding one's essence as its fundamental criterion. Another concept of good is the "absolute", objective good, realized as the intuitive cognition of God (Gluchman, 1997, p. 116). In a Spinozian view, subjective and objective concepts of good are both simply normative tools usable in the process of achieving one supreme ethical goal: the fullest activity of one's existence. In my opinion, ethics of social consequences shares this attitude towards morality and ethics with Spinoza. Considering the consequences of one's action is nothing but a specific mode of rationality, which itself is nothing but a specific mode of thinking. Rationality is, therefore, understood as an instrument for moral thinking and judging, and in relation to moral agency, it is always subjectively good. ${ }^{5}$ Objective good is characterized by Gluchman as a result of a wide portfolio of human activities aimed at selfperfection and perfection of the social community a moral agent belongs to (Gluchman, 1995,

\footnotetext{
${ }^{5}$ Thus we can say that in relation to moral agency, considering the consequences of one's action in the process of moral thinking and judging is good in itself. However, Gluchman advises to understand rationality as an end in itself, because it is only an instrument used to realize the good, or "in the battle against evil" (Gluchman, 1997, p. 60).
} 
p. 91). Perfection, thus, is the ultimate ethical goal, and in relation to the moral agent, freedom, accompanied by rational self-governance, is its highest degree. ${ }^{6}$

\section{Conclusion}

In a Spinozian view of morality and human life, it is necessary for a moral agent to actively participate in the world in order to make it more perfect, and thus also be more perfect. Actively participating in the human way means being helpful and useful to others by being guided by reason, and educating others that they live well and true to their essence only when they live under the sway of their own reason (Spinoza, 2002a, p. 359). Rational obligation of active participation is also present in ethics of social consequences, for example in the form of the value of (human) dignity, which, according to Júlia Polomská, motivates and obliges the moral agent to be active and to strive for good, and to act in accordance with moral requirements valid in society (Polomská, 2018, p. 145). In both theories, such obligations are prescriptive only to those who are rational.

I believe I have demonstrated the similarity of some elements of Spinoza's normative ethics to the prescriptive aspects of ethics of social consequences. It is not necessary, nor would it be accurate to term Spinoza as a consequentialist, because that would be equal to accusing him of preferring the right over the moral, or vice versa, which he never did. Ethics of social consequences, on the other hand, understandably prefers the right over the moral, but it does not completely disregard the motivational and intellectual moments of one's morality; it would be more useful, though, theoretically as well as practically, if it articulated its position in this regard more conclusively. However, focus on the consequences is not the only conceptual similarity found in both theories: the obligatory rational effort, emphasis on freedom as the final end, the concept of activity and agency of human beings, the theory of right and the theory of moral, the dualistic understanding of good, and the instrumental understanding of rationality are all shared by these two. To me, these similarities and aspects of said theories seem consistent and solid enough to use them in a reformulation of a complex contemporary ethical theory, a specific form of consequentialism funded by Spinoza's ontology and meta-ethics. The practical functionality and applicability of said theory is to be examined, but the practical potential of ethics of social consequences already seems to be sufficient. $^{7}$

According to this account, understanding establishes the desired action to be good, making it - through its motive - moral in its core. Nevertheless, such understanding must be adequately reviewed in reference to practice to create the right course of action. "A free man" must be aware of the inner causes of his, making him willing to perform a certain action, but he must also be aware of the causal and other relations taking place outside of his mind, which also means being aware of the fact that our actions, whatever their background might be, directly (or indirectly) affect the reality of objective existence and irreversibly become a part of it. Such a man is thus a consequentialist just as much as a principialist. I believe that through Spinoza's approach, it is possible to weaken the boundaries between principialist and consequentialist aspects of normative ethics, which could be productive in terms of broadening moral consideration, and by that, broadening human intellect. And ethics of social consequences, as a dynamic, open, and progressive theory, seems to be heading just this way.

\footnotetext{
${ }^{6}$ Freedom here refers to the concept of moral freedom in ethics of social consequences and the concept of freedom as blessedness in Spinoza's ethics. According to Gluchman, moral freedom lies in moral agent's abilities and faculties of actively creating, choosing, and realizing moral goals and values (Gluchman, 1997, p. 52). Spinoza's concept of freedom is identical with the ideal of a free man, or greatly rational mind, which I have examined sooner in the paper.

${ }^{7}$ Most recent practical applications of ethics of social consequences and the challenges that accompany them are to be found in edited volume Ethics of social consequences: Philosophical, applied and professional challenges (Gluchman, 2018).
} 


\section{Acknowledgement}

This paper is a part of the research project - VEGA 1/0629/15 Ethics of social consequences in context of contemporary ethical theories.

\section{References}

BOEHM, O. (2014): Kant's Critique of Spinoza. New York: Oxford University Press.

CARRIERO, J. (2011): Conatus and Perfection in Spinoza. In: Midwest Studies in Philosophy, 35(1), pp. 69-92.

DE DIJN, H. (1996): Spinoza: The Way to Wisdom. West Lafayette: Purdue University Press. DE DIJN, H. (2004): Ethics IV: the ladder, not the top. The provisional morals of the philosopher. In: Y. Yovel \& G. Segal (eds.): Ethica IV: Spinoza on Reason and the 'Free Man'. Papers Presented at the Fourth Jerusalem Conference. New York: Little Room Press, pp. 37-56.

GLUCHMAN, V. (1995): Etika konzekvencializmu [Ethics of consequentialism]. Prešov: ManaCon.

GLUCHMAN, V. (1996): Etika sociálnych dôsledkov a jej kontexty [Ethics of social consequences and its contexts]. Prešov: PVT.

GLUCHMAN, V. (1997): Spinoza's God and good. In: U. Nembach, H. Rusterholz \& P. M. Zulehner (eds.): Informationes Theologiae Europae: Internationales ökumenisches Jahrbuch für Theologie. Frankfurt am Main: Peter Lang, pp. 111-120.

GLUCHMAN, V. (2001): Teória správneho v etike sociálnych dôsledkov [Theory of right in ethics of social consequences]. In: Filosofický časopis, 49(4), pp. 633-654.

GLUCHMAN, V. (2003): Human being and morality in ethics of social consequences. Lewiston: The Edwin Mellen Press.

GLUCHMAN, V. (2008): Etika a reflexie morálky [Ethics and reflections of morality]. Prešov: FF PU.

GLUCHMAN, V. (2017): G. E. Moore and theory of moral/right action in ethics of social consequences. In: Ethics \& Bioethics (in Central Europe), 7(1-2), pp. 57-65.

GLUCHMAN, V., ed. (2018): Ethics of Social Consequences: Philosophical, Applied and Professional Challenges. Newcastle upon Tyne: Cambridge Scholars Publishing.

HOMAN, M. (2015): Rehumanizing Spinoza's free man. In: U. Goldenbaum \& Ch. Kluz (eds.): Doing without free will: Spinoza and contemporary moral problems. London: Lexington Books, pp. 75-96.

HÜBNER, K. (2014): Spinoza on being human and human perfection. In: M. J. Kisner \& A. Youpa (eds.): Essays on Spinoza's Ethical Theory. New York: Oxford University Press, pp. 124-142.

KALAJTZIDIS, J. (2013): Ethics of social consequences as a contemporary consequentialist theory. In: Ethics \& Bioethics (in Central Europe), 3(3-4), pp. 159-171.

LEBUFFE, M. (2007): Spinoza's Normative Ethics. In: Canadian Journal of Philosophy, 37(3), pp. 371-391.

MELAMED, Y. Y. (2011): Spinoza's Anti-Humanism: An Outline. In: C. Fraenkel, D. Perinetti \& J. E. H. Smith (eds.): The Rationalists: Between the Tradition and Innovation. New York: Springer, pp. 147-166.

NARVESON, J. (1970): Utilitarianism and moral norms. In: The Journal of Value Inquiry, 4(4), pp. 273-282.

POLOMSKÁ, J. (2018): Human Dignity within Ethics of Social Consequences. In: V. Gluchman (ed.): Ethics of Social Consequences: Philosophical, Applied and Professional Challenges. Newcastle upon Tyne: Cambridge Scholars Publishing, pp. 137-183. 
SPINOZA, B. (2002a): Ethics. In: B. Spinoza: Complete works, ed. M. L. Morgan, trans. S. Shirley. Indianapolis \& Cambridge: Hackett Publishing, pp. 213-382.

SPINOZA, B. (2002b): Principles of Cartesian Philosophy and Metaphysical Thoughts. In: B. Spinoza: Complete works, ed. M. L. Morgan, trans. S. Shirley. Indianapolis \& Cambridge: Hackett Publishing, pp. 108-212.

SPINOZA, B. (2002c): Short Treatise on God, Man, and His Well-Being. In: B. Spinoza: Complete works, ed. M. L. Morgan, trans. S. Shirley. Indianapolis \& Cambridge: Hackett Publishing, pp. 31-107.

SPINOZA, B. (2002d): Theological-Political Treatise. In: B. Spinoza: Complete works, ed. M. L. Morgan, trans. S. Shirley. Indianapolis \& Cambridge: Hackett Publishing, pp. 383-583. SPINOZA, B. (2002e): The Letters. In: B. Spinoza: Complete works, ed. M. L. Morgan, trans. S. Shirley. Indianapolis \& Cambridge: Hackett Publishing, pp. 755-959.

ZUOLO, F. (2016): Nature and morals: solving the riddle of Spinoza's metaethics. In: Revue philosophique de la France et de l'étranger, 141(1), pp. 23-40. 